\begin{tabular}{ccc} 
Tersedia online di: http://ejournal-balitbang.kkp.go.id/index.php/jppi & JURNAL \\
e-mail:jppi.puslitbangkan@ gmail.com & PENELITIAN \\
PERIKANAN & INDONESIA \\
JURNAL PENELITIANPERIKANANINDONESIA & Volume 26 Nomor 1 Maret 2020 \\
p-ISSN: 0853-5884 & e-ISSN: 2502-6542 \\
Nomor Akreditasi RISTEKDIKTI: 21/E/KPT/2018 & \\
\hline
\end{tabular}

\title{
KARAKTERISTIK PERIKANAN PUKAT CINCIN PELAGIS BESAR DI PERAIRAN SAMUDRA HINDIA (WPPNRI 572 DAN 573)
}

\section{CHARACTERISTIC OF PURSE SEINE LARGE PELAGIC FISHERY IN THE INDIAN OCEAN WATERS (FMA 572 AND 573)}

\author{
Irwan Jatmiko*1, Suciadi Catur Nugroho' ${ }^{1}$ dan Zulkarnaen Fahmi ${ }^{1}$ \\ ${ }^{1}$ Loka Riset Perikanan Tuna, Jl. Mertasari 140 Sidakarya, Denpasar, Bali 80224, Indonesia \\ Teregistrasi I tanggal: 29 September 2019; Diterima setelah perbaikan tanggal: 06 April 2020; \\ Disetujui terbit tanggal: 07 April 2020
}

\begin{abstract}
ABSTRAK
Pukat cincin merupakan salah satu jenis alat penangkapan ikan yang digunakan oleh nelayan di Indonesia untuk menangkap ikan pelagis termasuk tuna dan cakalang. Cakalang dan madidihang/tuna sirip kuning merupakan komoditas perikanan penting di Indonesia untuk kebutuhan pasar domestik dan ekspor. Penelitian ini bertujuan untuk mengetahui karakteristik alat tangkap pukat cincin pelagis besar terutama yang menangkap cakalang dan madidihang di perairan WPPNRI 572 dan 573 (Samudra Hindia). Pengumpulan data dilakukan selama tiga tahun dari 2016-2018 di 18 pelabuhan perikanan yang armadanya melakukan aktivitas penangkapan di perairan WPPNRI 572 dan 573. Indikasi proporsi ikan yang sudah dan belum matang gonad dihitung dengan membandingkan ukuran ikan dengan ukuran pertama kali matang gonad $(L m)$. Hasil penelitian menunjukkan bahwa alat tangkap pukat cincin sangat dominan dalam mengeksploitasi sumber daya cakalang dan madidihang dengan proporsi mencapai 95\% di WPPNRI 572 dan 66\% di WPPNRI 573. Kebanyakan ikan yang tertangkap didominasi oleh ikan yang belum matang gonad dengan proporsi sebesar $67 \%$ untuk cakalang dan $94 \%$ untuk madidihang. Hasil analisis menunjukkan bahwa pukat cincin tidak termasuk alat yang selektif untuk menangkap ikan madidihang. Selanjutnya untuk target ikan cakalang, ukuran mata jaring harus diperbesar untuk mencegah tertangkapnya ikan yang belum matang gonad.
\end{abstract}

Kata Kunci: Karakteristik; pukat cincin; pelagis besar; WPPNRI 572; WPPNRI 573

\begin{abstract}
Purse seine is one of dominant fishing gears used to catch pelagic species including skipjack and yellowfin tuna. They are two important commercial species in Indonesian as domestic and export commodities. This research aimed to analyze the characteristics of purse seine fishery focusing on skipjack and yellowfin tuna within FMA 572 and 573. All catch-effort data were collected from 18 fishing ports in three years, 2016-2018. All the vessels (purse seiners) were known to be actively fished within FMA 572 and 573. The proportion of mature and immature fish were calculated using the ratio of the fish length to its length at first maturity $(\mathrm{Lm})$. The results showed that purse seine was a dominant gear to catch skipjack tuna and yellowfin tuna covering95\% in FMA 572 and $66 \%$ in FMA 573, respectively. Most of the catches were dominated by immature fish with a proportion of $67 \%$ for skipjack tuna and $94 \%$ for yellowfin tuna. The analysis showed that purse seine is not an environmental-friendly gear to catchyellowfin tuna. Furthermore, for targeting skipjack tuna, the mesh-size of the net should be larger, allowing immature fish to escape from the gear.
\end{abstract}

Keywords: Characteristic; purse seine; large pelagic; FMA 572; FMA 573 


\section{PENDAHULUAN}

Pukat cincin merupakan salah satu jenis alat penangkapan ikan yang digunakan oleh nelayan skala kecil maupun besar/industri) untuk menangkap jenis ikan pelagis kecil maupun pelagis besar. Deskripsi pukat cincin ini pada umumnya berbentuk jaring persegi panjang dengan bagian atasnya dipasang pelampung, bagian bawahnya dipasang pemberat, dilengkapi tali kerut (purse line) serta memiliki kantong yang disebut "bunt" (Mahiswara et al., 2013). Beberapa jenis ikan hasil tangkapan pukat cincin adalah kelompok ikan pelagis termasuk di dalamnya adalah cakalang/skipjack tuna/SKJ (Katsuwonus pelamis) dan madidihang/tuna sirip kuning/yellowfin tuna/YFT ( Thunnus albacares).

Cakalang dan madidihang ialah komoditas penting yang termasuk dalam kelompok tuna, cakalang dan tongkol (TCT). Rata-rata total hasil tangkapan tuna dan cakalang Indonesia di Wilayah Pengelolaan Perikanan (WPPNRI) 572 dan 573 pada tahun 20052016 mencapai 1,6 juta ton/tahun. Dari nilai tersebut, cakalang menyumbang proporsi terbesar total hasil tangkapan tuna yang mana mencapai $48 \%$, diikuti oleh madidihang dengan proporsi sebesar $28 \%$ dari total kelompok tuna besar (DJPT, 2017).

Komoditas tongkol, cakalang dan tuna termasuk dalam prioritas dalam program pengelolaan perikanan oleh Kementerian Kelautan dan Perikanan (KKP). Hal ini diimplementasikan dengan menerbitkan Rencana
Pengelolaan Perikanan Tuna, Cakalang dan Tongkol (RPP-TCT) dalam Keputusan Kementerian Kelautan dan Perikanan Nomor: 107/KEPMEN-KP/2015 (Kepmen-KP, 2015). Adanya Keputusan Menteri ini diharapkan dapat menjaga kelestarian sumber daya TCT di Indonesia. Penelitian ini bertujuan untuk mengetahui karakteristik perikanan pukat cincin pelagis besar khususnya yang beroperasi di perairan Samudra Hindia (WPPNRI 572-573).

\section{BAHAN DAN METODE Pengumpulan Data}

Pengumpulan data dilakukan pada 18 pelabuhan (pendaratan ikan) yang armadanya melakukan operasi penangkapan di WPP 572 dan 573 (Gambar 1). Dari 18 pelabuhan tersebut, tiga diantaranya dilakukan pengumpulan data di atas kapal (pengamatan di laut) yaitu di Sibolga, Nizam Zachman dan Pondok Dadap. Sebanyak 5 trip kapal pukat cincin telah dikumpulkan datanya dengan ukuran kapal antara 48-149 GT dengan jumlah hari operasi penangkapan antara 7-31 hari. Daerah penangkapan pukat cincin berada di wilayah perairan teritorial, Zona Ekonomi Eksklusif (ZEE) dan di laut lepas (Gambar 1 dan Tabel 1). Dari ukuran kapal yang diperoleh, kemudian dikelompokkan ke dalam pukat cincin (purse seine) pelagis besar (PSPB) dan pukat cincin (purse seine) pelagis kecil (PSPK) (Permen-KP, 2016). Perbedaan antara PSPB dan PSPK dapat dilihat dari ukuran mata jaring (mesh size), panjang tali ris atas, daya lampu rumpon dan tonase kapal (Tabel 2).

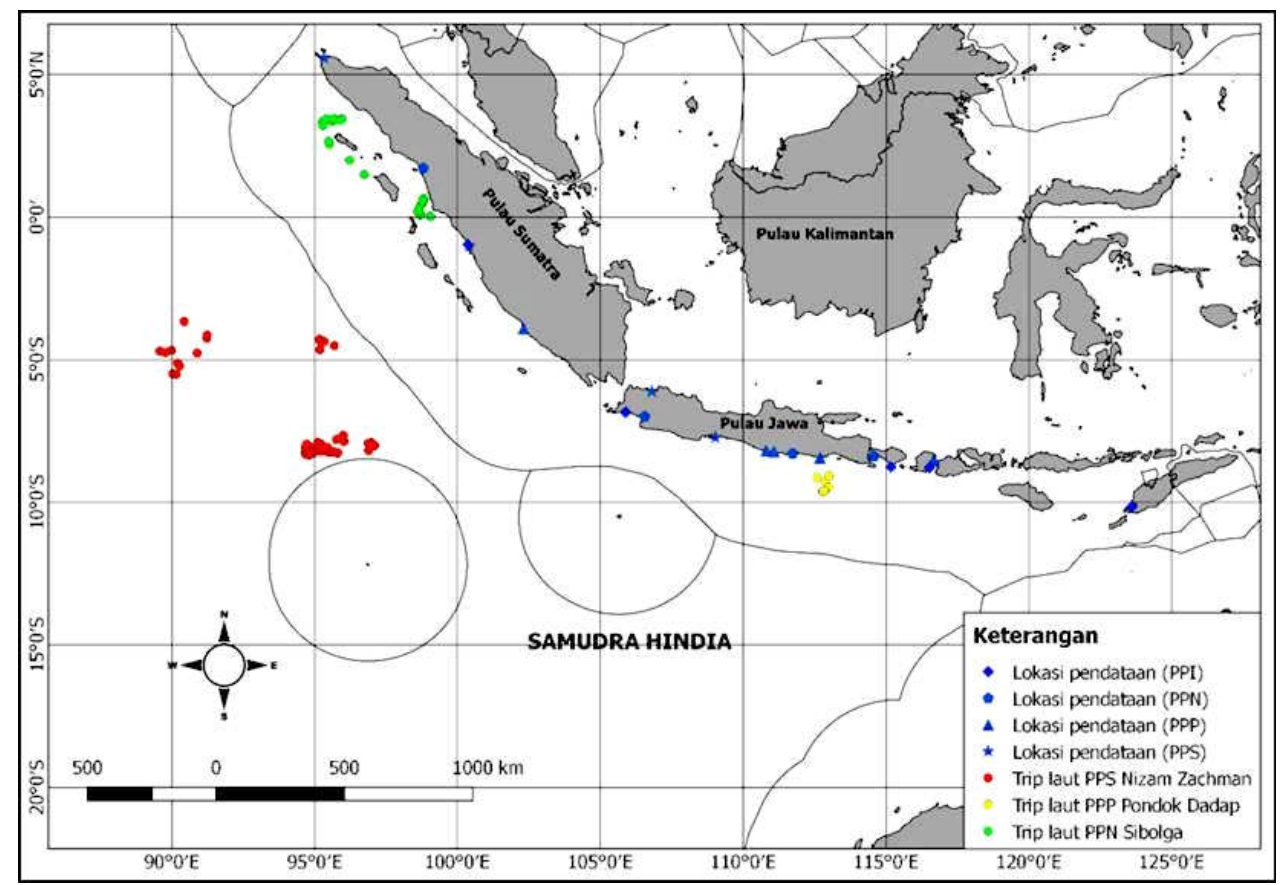

Gambar 1. Lokasi sampling dan daerah penangkapan pukat cincin dalam penelitian ini.

Figure 1. Sampling location and fishing ground of purse seine in this study. 
Tabel 1. Informasi opersional penangkapan kapal pukat cincin di Samudra Hindia

Table 1. Operational information of purse seine fishing vessels in Indian Ocean

\begin{tabular}{|c|c|c|c|c|c|c|}
\hline $\begin{array}{l}\text { No } \\
\text { Trip }\end{array}$ & Pelabuhan & Lintang & Bujur & $\begin{array}{c}\text { GT } \\
\text { Kapal }\end{array}$ & $\begin{array}{l}\text { Jumlah hari } \\
\text { operasi }\end{array}$ & $\begin{array}{l}\text { Jumlah } \\
\text { setting }\end{array}$ \\
\hline 1 & $\begin{array}{l}\text { PPS Nizam } \\
\text { Zachman }\end{array}$ & $\begin{array}{l}07^{\circ} 39^{\prime}-08^{\circ} 09^{\prime} \\
\text { LS }\end{array}$ & $94^{\circ} 40^{\prime}-97^{\circ} 06^{\prime}$ BT & 131 & 31 & 31 \\
\hline 2 & PPN Sibolga & $\begin{array}{l}00^{\circ} 02^{\prime}-00^{\circ} 39^{\prime} \\
\mathrm{LU}\end{array}$ & $98^{\circ} 37^{\prime}-99^{\circ} 04^{\prime}$ BT & 58 & 9 & 14 \\
\hline 3 & PPN Sibolga & $\begin{array}{l}01^{\circ} 30^{\prime}-03^{\circ} 28^{\prime} \\
\mathrm{LU}\end{array}$ & $95^{\circ} 16^{\prime}-96^{\circ} 44^{\prime}$ BT & 85 & 13 & 13 \\
\hline 4 & $\begin{array}{l}\text { PPP Pondok } \\
\text { Dadap }\end{array}$ & $\begin{array}{l}09^{\circ} 04^{\prime}-09^{\circ} 37^{\prime} \\
\text { LS }\end{array}$ & $\begin{array}{l}112^{\circ} 35^{\prime}-113^{\circ} 00^{\prime} \\
\text { BT }\end{array}$ & 48 & 7 & 7 \\
\hline 5 & $\begin{array}{l}\text { PPS Nizam } \\
\text { Zachman }\end{array}$ & $\begin{array}{l}03^{\circ} 08^{\prime}-05^{\circ} 46^{\prime} \\
\text { LS }\end{array}$ & $89^{\circ} 02^{\prime}-95^{\circ} 59^{\prime}$ BT & 149 & 16 & 16 \\
\hline
\end{tabular}

Tabel 2. Kategori pukat cincin pelagis besar (PSPB) dan pukat cincin pelagis kecil (PSPK) menurut PermenKP Tahun 2016

Tabel 2. Clasification of large pelagic and small pelagic purse seiner based on Ministerial Decree year 2016

\begin{tabular}{ccccc}
\hline $\begin{array}{c}\text { Pukat } \\
\text { cincin }\end{array}$ & $\begin{array}{c}\text { Mesh size } \\
\text { (inch) }\end{array}$ & Tali ris atas $(\mathbf{m})$ & $\begin{array}{c}\text { Daya lampu rumpon } \\
\text { (watt) }\end{array}$ & Tonase (GT) \\
\hline $\begin{array}{c}\text { Pelagis } \\
\text { besar }\end{array}$ & $>=2$ & $<=700$ & $<=16.000$ & $>10-30$ \\
& $>=2$ & $<=1.500$ & $<=16.000$ & $>30$ \\
\hline Pelagis kecil & $>=1$ & $<=300$ & $<=4.000$ & $<=10$ \\
& $>=1$ & $<=400$ & $<=8.000$ & $>10-30$ \\
& $>=1$ & $<=600$ & $<=16.000$ & $>30$ \\
& $>=1$ & $<=600$ & $<=16.000$ & $>30-100$ \\
\hline
\end{tabular}

Proses pengumpulan data dilakukan selama tiga tahun dari 2016-2018. Data yang dikumpulkan di pelabuhan berupa data hasil tangkapan, nama kapal, lama hari operasi di laut dan parameter biologi yaitu panjang cagak ikan $(\mathrm{cm})$. Sedangkan data yang dikumpulkan dari observasi di laut pada kapal pukat cincin berupa nama kapal, daerah penangkapan ikan dan ukuran panjang cagak ikan (cm).

\section{Analisis Data}

Hasil tangkapan per satuan upaya (CPUE) dihitung berdasarkan hasil tangkapan ikan $(\mathrm{kg})$ dibagi hari laut dalam satu trip. Proporsi ikan yang sudah dan belum matang gonad dihitung dengan membandingkan ukuran ikan dengan ukuran pertama kali matang gonad $(L m)$ dimana nilai $L m$ yang digunakan berdasarkan hasil penelitian sebelumnya yang dilakukan di Samudra Hindia dimana nilai $L m$ cakalang adalah 43 cmFL (Jatmiko et al., 2015) dan Lm madidihang adalah $95 \mathrm{cmFL}$ (Arnenda et al., 2018).

\section{HASIL DAN BAHASAN \\ Hasil}

\section{Deskripsi Kapal dan Alat Tangkap Pukat Cincin}

Spesifikasi alat tangkap pukat cincin secara umum relatif sama antara yang beroperasi di laut lepas dan ZEE (Tabel 3). Perbedaan yang cukup mencolok adalah ukuran kapal yang digunakan. Kapal pukat cincin yang beroperasi di laut lepas memiliki ukuran 131-149 GT. Ukuran ini lebih besar dari kapal yang beroperasi di perairan ZEE dengan ukuran berkisar antara 48-85 GT. Selain itu, beberapa bagian seperti ukuran mata jaring, panjang tali pelampung dan ketebalan cincin lebih besar pada kapal yang beroperasi di laut lepas daripada di perairan ZEE. Jaring pukat cincin berbentuk trapesium dengan panjang jaring bagian atas lebih panjang daripada panjang jaring bagian bawah (Gambar 2). 
Tabel 3. Spesifikasi alat tangkap pukat cincin yang beroperasi di laut lepas dan perairan ZEE Table 3. Specification of purse seiners which operated in high seas and EEZ waters

\begin{tabular}{lll}
\hline Spesifikasi & Laut Lepas & ZEE \\
\hline Gross Ton & $131-149 \mathrm{GT}$ & $48-85 \mathrm{GT}$ \\
Panjang jaring & $800-1400 \mathrm{~m}$ & $480-1000 \mathrm{~m}$ \\
Lebar Jaring & $80 \mathrm{~m}$ & $60-135 \mathrm{~m}$ \\
Ukuran mata jaring & $4 \mathrm{inci}$ & $2-4 \mathrm{inci}$ \\
Ukuran mata jaring bagian kantong & 2 inci & 1 inci \\
Bahan Pelampung & busa plastic & busa plastic \\
Diameter pelampung & $14,5 \mathrm{~cm}$ & $12-14,3 \mathrm{~cm}$ \\
Panjang pelampung & $20 \mathrm{~cm}$ & $17-18,8 \mathrm{~cm}$ \\
Jarak antar pelampung & $21 \mathrm{~cm}$ & $10-20,9 \mathrm{~cm}$ \\
Panjang tali pelampung & $800-1400 \mathrm{~m}$ & $500-1400 \mathrm{~m}$ \\
Bahan tali pelampung & Polypropylene & Polypropylene \\
Diameter tali pelampung & $36 \mathrm{~mm}$ & $10-36 \mathrm{~mm}$ \\
Bahan tali ris atas dan bawah & Polypropylene & Polypropylene \\
Diameter tali ris atas dan bawah & $36 \mathrm{~mm}$ & $36 \mathrm{~mm}$ \\
Bahan pemberat & Timah & Timah \\
Diameter pemberat & $32 \mathrm{~mm}$ & $30 \mathrm{~mm}$ \\
Panjang pemberat & $50 \mathrm{~mm}$ & $50 \mathrm{~mm}$ \\
Jarak antar pemberat & $150 \mathrm{~mm}$ & $150 \mathrm{~mm}$ \\
Bahan cincin jaring & baja & Baja \\
Diameter cincin jaring & $120 \mathrm{~mm}$ & $110-130 \mathrm{~mm}$ \\
Ketebalan cincin jaring & $24 \mathrm{~mm}$ & $20 \mathrm{~mm}$ \\
\hline
\end{tabular}

Sumber data: wawancara oleh petugas pemantau di atas kapal (onboard observer).

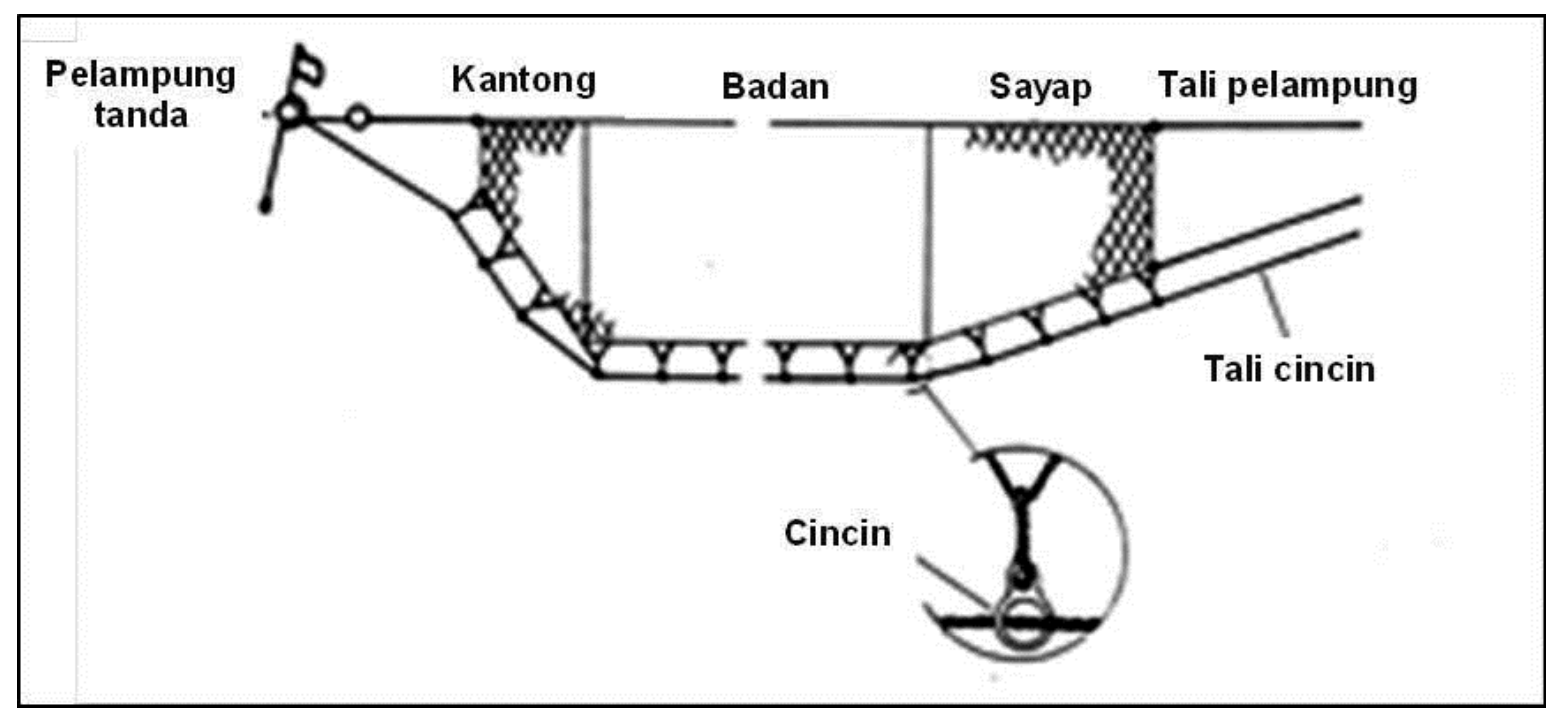

Gambar 2. llustrasi alat tangkap pukat cincin. (Sumber: FAO).

Figure 2. Ilustration of purse seine (Source: $F A O$ ).

\section{Hasil Tangkapan Pukat Cincin}

Total hasil tangkapan cakalang berasal dari perairan WPP 572 sebesar 22.000 ton atau hampir dua kali lipat hasil tangkapan di perairan WPP 573 yaitu sebesar 11.500 ton. Demikian juga hasil tangkapan madidihang di WPP 572 juga lebih besar daripada di WPP 573 yaitu sebesar 3.900 ton dan 3.500 ton. Dari total hasil tangkapan tersebut, dapat dilihat bahwa alat tangkap pukat cincin sangat berkontribusi terhadap hasil tangkapan cakalang dan madidihang dengan persentase mencapai $95 \%$ di WPP 572 dan 66\% di WPP 573 (Tabel 4).

Total hasil tangkapan cakalang dan madidihang dengan alat tangkap pukat cincin di WPP 572 berdasarkan tipe pelabuhan hampir semuanya didaratkan di PP. Nusantara dengan proporsi sebesar 99\%. Sedangkan di WPP 573 hasil tangkapan kedua komoditas tersebut banyak didaratkan di PP. Samudra dengan proporsi $70 \%$ untuk cakalang dan $99 \%$ untuk madidihang (Tabel 5). 
Tabel 4. Proporsi hasil tangkapan cakalang dan madidihang berdasarkan jenis alat penangkapan ikan di WPP 572 dan 573 pada tahun 2016-2018

Table 4. Catch proportion of skipjack tuna and yellowfin tuna based on fishing gear in FMA 572 and 573 in 2016-2018

\begin{tabular}{|c|c|c|c|c|c|c|c|c|}
\hline \multirow{3}{*}{$\begin{array}{l}\text { Komoditas } \\
\text { WPP } \\
\text { Hasil } \\
\text { tangkapan }\end{array}$} & \multicolumn{4}{|c|}{ Cakalang } & \multicolumn{4}{|c|}{ Madidihang } \\
\hline & \multicolumn{2}{|c|}{ WPP 572} & \multicolumn{2}{|c|}{ WPP 573} & \multicolumn{2}{|c|}{ WPP 572} & \multicolumn{2}{|c|}{ WPP 573} \\
\hline & (kg) & (\%) & (kg) & (\%) & (kg) & (\%) & (kg) & (\%) \\
\hline Bagan & 75.863 & 0,34 & & & 4.076 & 0,10 & & \\
\hline $\begin{array}{l}\text { Jaring } \\
\text { insang }\end{array}$ & 5.334 & 0,02 & 119.858 & 0,97 & & & 1.211 & 0,03 \\
\hline & 136.936 & 0,62 & 1.477 .881 & 12,01 & 12.129 & 0,29 & 411.163 & 11,22 \\
\hline $\begin{array}{l}\text { Pancing } \\
\text { ulur }\end{array}$ & 18.452 & 0,08 & 2.507 .340 & 20,38 & 19.126 & 0,46 & 799.025 & 21,80 \\
\hline $\begin{array}{l}\text { Pukat } \\
\text { cincin }\end{array}$ & 21.853.998 & 98,93 & 8.186 .537 & 66,54 & 3.895 .259 & 92,98 & 2.445 .510 & 66,73 \\
\hline $\begin{array}{l}\text { Rawal } \\
\text { tuna }\end{array}$ & & & 11.175 & 0,09 & 258.804 & 6,18 & 7.610 & 0,21 \\
\hline Total & 22.090 .583 & 100 & 12.302 .791 & 100 & 4.189.394 & 100 & 3.664 .519 & 100 \\
\hline
\end{tabular}

Tabel 5. Hasil tangkapan cakalang dan madidihang dari pukat cincin menurut tipe pelabuhan pada tahun 2016-2018.

Table 5. Catch of skipjack tuna and yellowfin tuna based on type of fishing port in 2016-2018.

\begin{tabular}{|c|c|c|c|c|c|c|c|c|}
\hline \multirow{3}{*}{$\begin{array}{l}\text { Komoditas } \\
\text { WPP } \\
\begin{array}{l}\text { Hasil } \\
\text { tangkapan }\end{array} \\
\end{array}$} & \multicolumn{4}{|c|}{ Cakalang } & \multicolumn{4}{|c|}{ Madidihang } \\
\hline & \multicolumn{2}{|c|}{ WPP 572} & \multicolumn{2}{|c|}{ WPP 573} & \multicolumn{2}{|c|}{ WPP 572} & \multicolumn{2}{|c|}{ WPP 573} \\
\hline & $(\mathrm{kg})$ & $(\%)$ & $(\mathrm{kg})$ & $(\%)$ & $(\mathrm{kg})$ & $(\%)$ & (kg) & $(\%)$ \\
\hline PP. Ikan & 11.351 & 0,05 & 624.960 & 5,08 & 11.218 & 0,27 & 342.540 & 9,35 \\
\hline PP. Pantai & 331.639 & 1,50 & 4.503 .259 & 36,60 & & 0,00 & 587.356 & 16,03 \\
\hline PP. Nusantara & 21.634 .561 & 97,94 & 1.477 .365 & 12,01 & 3.874 .671 & 92,49 & 300.658 & 8,20 \\
\hline PP. Samudra & 113.032 & 0,51 & 5.697 .207 & 46,31 & 303.505 & 7,24 & 2.433 .965 & 66,42 \\
\hline Total & 22.090 .583 & 100 & 12.302.791 & 100 & 4.189.394 & 100 & 3.664 .519 & 100 \\
\hline
\end{tabular}

Total hasil tangkapan dari dua trip pukat cincin pelagis besar (PSPB) sebesar 69,5 ton dan didominasi jenis cakalang dengan proporsi sebesar $49,24 \%$. Kemudian diikuti oleh jenis ikan layang dan madidihang dengan proporsi masing-masing sebesar $26,89 \%$ dan $22,26 \%$. Sedangkan total hasil tangkapan dari tiga trip pukat cincin pelagis kecil (PSPK) sebesar 54,9 ton dan didominasi jenis ikan layang dengan proporsi sebesar $39,58 \%$, kemudian diikuti oleh madidihang dan cakalang dengan proporsi masingmasing sebesar $28,21 \%$ dan $19,71 \%$ (Gambar 3).
Analisis hasil tangkapan per satuan upaya (CPUE) menunjukkan bahwa rata-rata hasil tangkapan cakalang bagi PSPB sebanyak $1.000 \mathrm{~kg} /$ trip. Hasil tangkapan ini lebih besar sekitar $225 \mathrm{~kg}$ dibandingkan yang hasil tangkapan dengan PSPK yaitu sebesar $773 \mathrm{~kg} /$ trip. Hal sebaliknya terjadi pada komoditas madidihang. Rata-rata hasil tangkapan madidihnag pada PSPB hanya sekitar $400 \mathrm{~kg} /$ trip. Hasil tangkapan ini lebih kecil sekitar separuh dibandingkan dengan ikan yang tertangkap dengan PSPK yang mencapai 860 kg/trip (Gambar 4). 

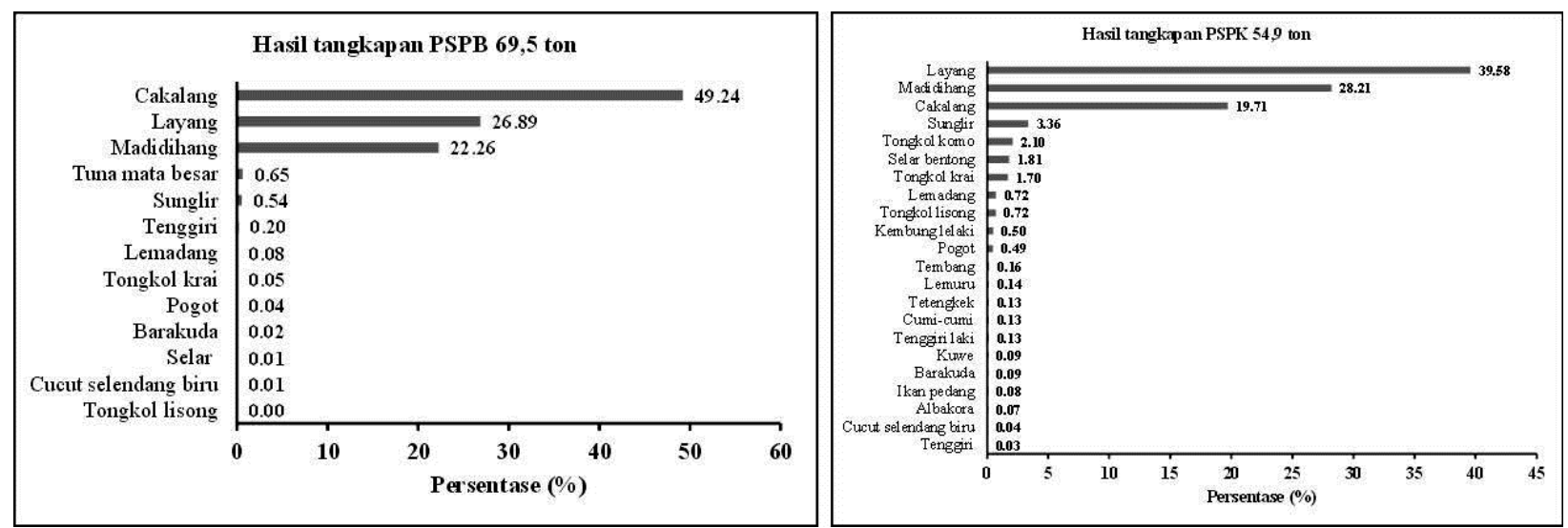

Gambar 3. Komposisi hasil tangkapan PSPB (atas) dan PSPK (bawah).

Figure 3. Catch composition of large pelagic purse seine (above) and small pelagic purse seine.
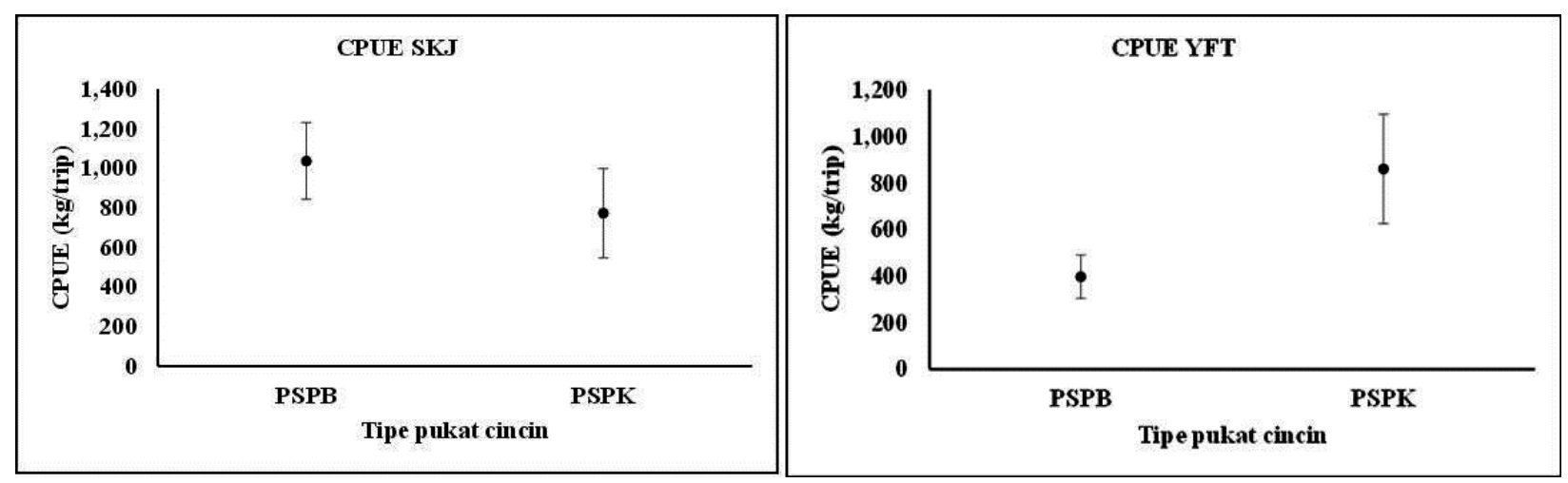

Gambar 4. CPUE cakalang dan madidihang berdasarkan tipe pukat cincin.

Figure 4. CPUE of skipjack tuna and yellowfin tuna based on purse seine types.

\section{Aspek Biologi Cakalang dan Madidihang Tertangkap Pukat Cincin}

Total sampel ikan yang diukur dari pengamatan di laut sebanyak 4.119 ekor terdiri dari cakalang sebanyak 2.179 ekor dan madidihang sebanyak 1.940 ekor. Secara umum, rata-rata panjang cakalang dan madidihang yang tertangkap di laut lepas lebih besar daripada di ZEE. Rata-rata panjang cakalang tertangkap di laut lepas sebesar 40,69 cm lebih panjang sekitar $5 \mathrm{~cm}$ daripada cakalang tertangkap di perairan ZEE yang hanya sebesar $35,36 \mathrm{~cm}$. Hal yang serupa juga terjadi pada madidihang yang tertangkap di laut lepas dengan rata-rata panjang 43,67 $\mathrm{cm}$ lebih besar daripada di ZEE sebesar $41,02 \mathrm{~cm}$ (Tabel 6).

Tabel 6. Rata-rata ukuran cakalang dan madidihang tertangkap berdasarkan zonasi daerah penangkapan Table 6. Average length of skipjack tuna and yellowfin tuna caught based fishing ground

\begin{tabular}{lrrrrrrrr}
\hline & \multicolumn{4}{c}{ Cakalang } & \multicolumn{4}{c}{ Madidihang } \\
\cline { 2 - 10 } \multicolumn{1}{c}{ Daerah Penangkapan } & \multicolumn{1}{c}{ N } & Min & Max & Rata-rata & \multicolumn{1}{c}{ N } & Min & Max & Rata-rata \\
\hline Laut Lepas & 1.720 & 19 & 68 & 40,69 & 1.156 & 23 & 161 & 43,67 \\
ZEE & 459 & 17 & 67 & 35,36 & 784 & 16 & 158 & 41,02 \\
\hline Total & 2.179 & 17 & 68 & 39,57 & 1.940 & 16 & 161 & 42,60 \\
\hline
\end{tabular}

Secara umum, cakalang yang tertangkap dalam kondisi belum matang gonad dengan proporsi sebesar $80 \%$, baik yang tertangkap PSPB maupun PSPK.

Bahkan untuk madidihang yang tertangkap semuanya dalam kondisi belum matang gonad dengan proporsi sebesar 99\% (Gambar 5). 


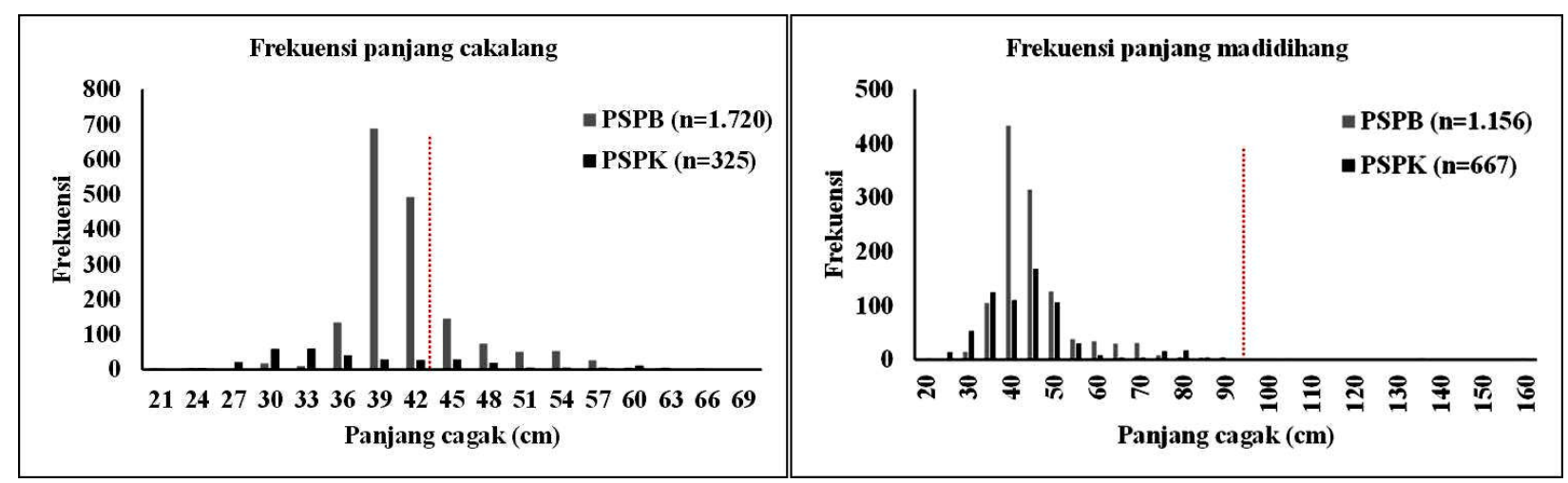

Gambar 5. Sebaran ukuran ikan tertangkap dan matang gonad untuk cakalang dan madidihang berdasarkan tipe pukat cincin.

Figure 5. Length destribution of fish and matured size for skipjack tuna and yellowfin tuna based on purse seine types.

\section{Bahasan}

Cakalang dan madidihang di perairan Samudra Hindia WPP 572 dan 573 dieksploitasi dengan mengoperasikan enam jenis alat penangkapan ikan yaitu: bagan, jaring insang, pancing tonda, pancing ulur, pukat cincin dan rawai tuna. Hal yang serupa juga disampaikan oleh Diniah et al. (2001) yang menyatakan bahwa sumberdaya ikan pelagis besar (tuna dan sejenisnya) dieksplotasi oleh berbagai jenis alat tangkap seperti rawai tuna, pukat cincin, huhate, pancing ulur dan pancing tonda. Terdapat dua tipe usaha perikanan tuna yaitu skala kecil dan skala industri. Pada umumnya, perikanan skala kecil didominasi oleh jaring insang, pancing tonda, pancing ulur dan pukat cincin, sedangkan perikanan skala industri didominasi oleh alat tangkap rawai tuna (Mertha et al., 2006). Dalam penelitian ini, pukat cincin pelagis besar (PSPB) termasuk dalam skala industri, sedangkan pukat cincin pelagis kecil (PSPK) termasuk dalam perikanan skala kecil.

Kapal pukat cincin yang beroperasi di Samudra Hindia umumnya menggunakan rumpon sebagai alat bantu penangkapan. Penggunaan rumpon ini dapat meningkatkan aktivitas penangkapan menjadi lebih efektif dan efisien. Meskipun demikian, pengguanaan rumpon secara berlebihan dapat merusak ekosistem perairan (Yusfiandayani, 2013). Salah satu cara untuk mengatur penggunaan rumpon adalah dengan menempatkan petugas pemantau selama operasi penangkapan. Hal ini penting karena penempatan rumpon perlu diatur dengan jarak tertentu agar tidak membatasi pola migrasi ikan dan tidak menjadi pagar pembatas secara ekologis (Dagorn et al., 2013). Kementerian Kelautan dan Perikanan sendiri telah membuat ketentuan tentang jarak antara rumpon yang satu dengan rumpon yang lain tidak kurang dari 10 mil laut (Permen-KP, 2014).
Rata-rata panjang cagak (FL) cakalang yang tertangkap dengan pukat cincin di perairan WPP 572 dan WPP 573 masing-masing sebesar $35,5 \mathrm{~cm}$ dan $37,7 \mathrm{~cm}$. Nilai ini lebih kecil daripada cakalang yang tertangkap dengan huhate di Perairan Teluk Bone dengan rata-rata panjang cagak $48,5 \mathrm{~cm}$. Namun lebih besar daripada cakalang yang tertangkap dengan payang juga di Perairan Teluk Bone dengan rata-rata panjang cagak $32,6 \mathrm{~cm}$ (Mallawa et al., 2012). Ratarata panjang cagak cakalang dalam penelitian ini juga lebih kecil daripada cakalang yang tertangkap dengan alat tangkap pancing tonda yang didaratkan di PPN Palabuhanratu dengan nilai $40,0 \mathrm{~cm}$ (Nurdin \& Panggabean, 2017).

Selanjutnya rata-rata panjang cagak (FL) madidihang yang tertangkap dengan pukat cincin di WPP 572 adalah $38,8 \mathrm{~cm}$ sedang di WPP 573 adalah $40,7 \mathrm{~cm}$. Nilai ini jauh lebih kecil daripada ikan madidihang yang tertangkap dengan rawai tuna di WPP 572 dengan panjang cagak 129,0 cm (Nugroho et al., 2018) dan di WPP 573 dengan panjang cagak $132,5 \mathrm{~cm}$ (Jatmiko et al., 2016). Selain itu, rata-rata panjang madidihang yang tertangkap dalam penelitian ini juga lebih kecil dibanding ikan yang tertangkap oleh pancing ulur di Samudra Hindia dengan rata-rata panjang cagak 129,3 cm (Muhammad \& Barata, 2012).

Kebanyakan ikan yang tertangkap dengan pukat cincin dalam kondisi belum matang gonad dengan proporsi $67 \%$ untuk cakalang dan $94 \%$ untuk madidihang. Kondisi ini tidak ideal untuk menjaga keberlanjutan populasi ikan tersebut. Ikan perlu memijah minimal satu kali untuk menjaga kelestarian hidupnya (Lappalainen et al., 2016; King, 2010). Oleh karena itu, diperlukan upaya kuat dalam pengelolaan periknanan pukat cincin di Samudra Hindia. Terutama untuk komoditas madidihang yang statusnya memang 
sudah lebih tangkap (overfishing) di wilayah perairan Samudra Hindia secara keseluruhan (IOTC, 2018).

Bagi ikan cakalang, statusnya masih sehat (underfishing). Ketahanan cakalang ini salah satunya disebabkan karena kemampuannya untuk tumbuh secara cepat. Pertumbuhan cakalang merupakan yang tercepat dibandingkan jenis tuna lainnya (Murua et al., 2017). Meskipun demikian, jika banyak cakalang yang belum matang gonad tertangkap, diperkirakan dalam waktu beberapa tahun ke depan akan mengalami status lebih tangkap.

Kondisi ini bukan hanya akan menimbulkan kerugian secara ekologis tetapi juga kerugian secara ekonomis karena hasil tangkapan ikan yang tertangkap lebih kecil dibanding saat kondisi yang dapat dicapai secara optimal (Diekert, 2011). Salah satu metode untuk mencegah growth overfishing ini adalah dengan memperbesar ukuran mata jaring (mesh size). Metode ini berhasil digunakan pada alat tangkap bubu dengan komoditas ikan-ikan karang di Jamaika. Dengan metode ini, hasil tangkapan ikan karang meningkat secara signifikan setelah tiga tahun sejak penambahan ukuran mata jaring digunakan (Sary et al., 1997).

Penempatan petugas pemantau (observer) di atas kapal juga dapat diterapkan untuk memantau aktivitas penangkapan pukat cincin dan hasil tangkapannya. Sejak tahun 2010, di Perairan Samudra Pasifik, Western and Central Pacific Fisheries Commission (WCPFC) telah mewajibkan seluruh armada pukat cincin yang beroperasi di wilayah antara 20 Lintang Utara hingga 20 Lintang Selatan (WCPFC, 2018). Sedangkan di Perairan Samudra Hindia, Indian Ocean Tuna Commission (IOTC) menerapkan program pemantau regional untuk memonitor aktivitas alih muat hasil tangkapan di laut (IOTC, 2011). Di Indonesia, program pemantauan di atas kapal ini pertama kali dilakukan pada tahun 2005 pada perikanan rawai tuna yang berbasis di Pelabuhan Benoa (Jatmiko et al., 2015). Program ini kemudian diperkuat dengan Peraturan Menteri tentang pemantau kapal penangkap ikan dan kapal pengangkut ikan (Permen-KP, 2013). Peraturan ini mengatur secara rinci tugas dan fungsi petugas pemantau (observer) serta kewajiban pemilik kapal untuk memfasilitasi program pemantauan ini.

\section{KESIMPULAN}

Armada pukat cincin sangat mendominasi dalam pemanfaatan sumberdaya cakalang dan madidihang di perairan Samudra Hindia di WPP 572 dan 573. Meskipun demikian, ukuran ikan yang tertangkap didominasi oleh ikan yang belum matang gonad mencapai $67 \%$ untuk cakalang dan 94\% untuk madidihang. Oleh karena itu, diperlukan aturan yang ketat untuk mengatur operasional penangkapan dengan pukat cincin. Penggunaan alat tangkap pukat cincin sangat tidak direkomendasikan untuk menangkap madidihang karena hampir semua ikan yang tertangkap belum mengalami matang gonad. Alat tangkap yang direkomendasikan untuk menangkap madidihang adalah rawai tuna dan pancing ulur. Kedua alat tangkap ini umumnya menangkap ikan dewasa yang diduga telah melakukan pemijahan, sehingga dapat menjaga kelestarian sumberdaya madidihang. Sedangkan untuk cakalang, aturan yang ketat perlu diterapkan salah satunya dengan penambahan ukuran mata jaring, sehingga ikan yang masih muda dapat meloloskan diri dan memiliki peluang untuk melakukan pemijahan. Hal ini perlu dilakukan untuk menjaga kelestarian sumber daya ikan cakalang dan madidihang di perairan Samudra Hindia.

\section{PERSANTUNAN}

Penelitian ini dibiayai dari DIPA kegiatan riset Loka Riset Perikanan Tuna (LRPT) pada tahun 2016-2018. Peneliti mengucapkan terima kasih kepada para enumerator dan pemantau ilmiah di LRPT yang telah membantu dalam proses pengumpulan data penelitian ini. Penulis pertama sebagai konstributor utama dalam paper ini.

\section{DAFTAR PUSTAKA}

Arnenda, G.L., Jatmiko, I., \& Kusdinar, A. (2018). Biologi reproduksi hasil tangkapan madidihang ( Thunnus albacares Bonnaterre, 1788) di Samudra Hindia Bagian Timur. Jurnal Kelautan dan Perikanan Terapan. 1(2), 55-62. doi: http:// dx.doi.org/10.15578/jkpt.v1i2.7261.

Dagorn, L., Holland, K.N., Restrepo, V., \& Moreno, G. (2013). Is it good or bad to fish with FADs? What are the real impacts of the use of drifting FADs on pelagic marine ecosystems? Fish and Fisheries. 14, 391-415. doi: https://doi.org/10.1111/ j.1467-2979.2012.00478.x.

Diekert, F.K. (2011). Growth overfishing: The race to fish extends to the dimension of size. Environmental and Resource Economics. doi: 10.1007/s10640-012-9542-x.

Diniah, Monintja, D.R.., \& Ardianto, A. (2006). Teknologi rumpon laut dalam sebagai alat bantu pemanfaatan sumberdaya cakalang dalam Sondita, M.F.A \& I, Solihin (Editor). Buku Kumpulan Pemikiran Teknologi Perikanan 
Tangkap yang Bertanggungjawab. FPIK IPB. Bogor. p. $36-42$.

Direktorat Jenderal Perikanan Tangkap (DJPT). (2017). Statistik Perikanan Tangkap Indonesia 2016 (p. 203). Jakarta: Direktorat Jenderal Perikanan Tangkap, Kementerian Kelautan dan Perikanan.

Indian Ocean Tuna Commission. (2018). Report of the $20^{\text {th }}$ Session of the IOTC Working Party on Tropical Tunas (p. 131). IOTC-2018-WPTT20-R[E].

Indian Ocean Tuna Commission. (2011). On A Regional Observer Scheme. Victoria, Seychelles.

Jatmiko, I., Hartaty, H., \& Nugraha, B. (2016). Estimation of yellowfin tuna production landed in Benoa Port with weight-weight, length-weight relationships and condition factor approaches. Ind. Fish. Res. J, 22(2), 77-84. doi: http://dx.doi.org/ 10.15578/ifr.22.2.2016.77-84.

Jatmiko, I., Nugraha, B., \& Satria, F. (2015). Capaian perkembangan program pemantau pada perikanan rawai tuna di Indonesia. Marine Fisheries. 6(1), 19. doi: https://doi.org/10.29244/jmf.6.1.23-31.

Jatmiko, I., Hartaty, H., \& Bahtiar, A. (2015). Biologi reproduksi hasil tangkapan ikan cakalang (Katsuwonus pelamis) di Samudra Hindia Bagian Timur. BAWAL. 7(2), 87-94. doi: http://dx.doi.org/ 10.15578/bawal.7.2.2015.87-94.

Keputusan Menteri KP. (2015). Kepmen-KP Nomor: 107/KEPMEN-KP/2015 Tentang Rencana Pengelolaan Perikanan Tuna, Cakalang dan Tongkol. Kementerian Kelautan dan Perikanan, Jakarta.

King, M. (2010). Fisheries Biology, Assessment and Management, Second Edition (p. 381). Oxford, England: Blackwell Publising Ltd.

Lappalainen, A., Saks, L., Sustar, M., Heikinheimo, O., Jurgens, K., Kokkonen, E., Kurkilahti, M., Verliin, A., \& Vetemaa, M. (2016). Length at maturity as potential indicator of fishing pressure effects on coastal pikeperch (Sander lucioperca) stocks in the northern Baltic Sea. Fisheries Research. 174(2016), 47-57. doi: https://doi.org/ 10.1016/j.fishres.2015.08.013.

Mahiswara, Budiarti, T.W., \& Baihaqi. (2013). Karakteristik teknis alat tangkap pukat cincin di Perairan Teluk Apar, Kabupaten Paser, Kalimantan Timur. J.Lit.Perikan.Ind. 19(1), 1-7. doi: http:// dx.doi.org/10.15578/jppi.19.1.2013.1-7.
Mallawa, A., Musbir, Amir, F., \& Marimba, A. (2012). Struktur ukuran ikan cakalang (Katsuwonus pelamis) menurut musim, daerah dan teknologi penangkapan di Perairan Luwu Teluk Bone, Sulawesi Selatan. Jurnal Balik Diwa. 3(2), 29-38. doi: http://repository.unhas.ac.id/handle/ $123456789 / 7200$.

Mertha, I.G.S., Nasrullah, A., \& Nurhuda. N. (2006). Perkembangan perikanan tuna di Palabuhanratu. J.Lit.Perikan.Ind. 12(2), 117-127. http://dx.doi.org/ 10.15578/jppi.12.2.2017.117-127.

Muhammad, N., \& Barata, A. (2012). Struktur ukuran ikan madidihang (Thunnus albacares) yang tertangkap pancing ulur di sekitar rumpon Samudra Hindia selatan Bali dan Lombok. BAWAL. 4(3), 161-167. doi: http://dx.doi.org/10.15578/ bawal.4.3.2012.161-167.

Murua, H., Rodriguez-Marin, E., Neilson, J.D., Farley, J.H., \& Juan Jorda, M.J. (2017). Fast versus slow growing tuna species: age, growth, and implications for population dynamics and fisheries management. Reviews in Fish Biology and Fisheries. 27(4), 733-773. doi: 10.1007/s11160-017-9474-1.

Nugroho, S.C., Jatmiko, I., \& Wujdi, A. (2018). Pola pertumbuhan dan faktor kondisi madidihang, Thunnus albacares (Bonnaterre, 1788) di Samudra Hindia Bagian Timur. Jurnal Iktiologi Indonesia. 18(1), 13-21. doi: https://doi.org/10.32491/ jii.v18i1.371.

Nurdin, E., \& Panggabean, A.S. (2017). Musim penangkapan dan struktur ukuran cakalang (Katsuwonus pelamis Linnaeus, 1758) di sekitar rumpon di Perairan Palabuhanratu. J.Lit.Perikan.Ind. 23(4), 299-308. doi: http:// dx.doi.org/10.15578/jppi.23.4.2017.299-308.

Peraturan Menteri KP. (2016). Permen-KP Nomor: 71/ PERMEN-KP/2016 Tentang Jalur Penangkapan Ikan Dan Penempatan Alat Penangkapan Ikan Di Wilayah Pengelolaan Perikanan Negara Republik Indonesia. Kementerian Kelautan dan Perikanan, Jakarta.

Peraturan Menteri KP. (2014). Permen-KP Nomor: 26/ PERMEN-KP/2014 Tentang Rumpon. Kementerian Kelautan dan Perikanan, Jakarta.

Peraturan Menteri KP. (2013). Permen-KP Nomor: 26/ PERMEN-KP/2014 Tentang Pemantau Kapal Penangkap Ikan dan Kapal Pengangkut Ikan. Kementerian Kelautan dan Perikanan, Jakarta. 
Peraturan Menteri KP. (2012). Permen-KP Nomor: PER.08/MEN/2012 Tentang Kepelabuhanan Perikanan. Kementerian Kelautan dan Perikanan, Jakarta.

Sary, Z., Oxenford, H.A., \& Woodley, J.D. (1997). Effects of an increase in trap mesh size on an overexploited coral reef fishery at Discovery Bay, Jamaica. Marine Ecology Progress Series. 154, 107-120.
Western and Central Pacific Fisheries Commission. (2018). Guidelines for the Regional Observer Programme. Pohnpei, Micronesia.

Yusfiandayani, R. (2013). Fish aggregating devices in Indonesia: Past and present status on sustainable capture fisheries. Galaxea, Journal of Coral Reef Studies. (Special Issue) 260-268. doi: https://doi.org/10.3755/galaxea.15.260. 